Article

\title{
Plasma Exchange or Immunoadsorption in Demyelinating Diseases: A Meta-Analysis
}

\author{
Mark Lipphardt, Manuel Wallbach 1 and Michael J. Koziolek* \\ Department of Nephrology and Rheumatology, University Medical Center Göttingen, Robert-Koch-Str. 40, \\ D-37075 Goettingen, Germany; mark.lipphardt@med.uni-goettingen.de (M.L.); \\ manuel.wallbach@med.uni-goettingen.de (M.W.) \\ * Correspondence: mkoziolek@med.uni-goettingen.de; Tel.: +49-55-1396-5751; Fax: +49-55-1396-5752
}

Received: 11 May 2020; Accepted: 18 May 2020; Published: 25 May 2020

\begin{abstract}
Multiple sclerosis (MS) is an inflammatory disease mainly affecting the central nervous system. In MS, abnormal immune mechanisms induce acute inflammation, demyelination, axonal loss, and the formation of central nervous system plaques. The long-term treatment involves options to modify the disease progression, whereas the treatment for the acute relapse has its focus in the administration of high-dose intravenous methylprednisolone (up to $1000 \mathrm{mg}$ daily) over a period of three to five days as a first step. If symptoms of the acute relapse persist, it is defined as glucocorticosteroid-unresponsive, and immunomodulation by apheresis is recommended. However, several national and international guidelines have no uniform recommendations on using plasma exchange (PE) nor immunoadsorption (IA) in this case. A systematic review and meta-analysis was conducted, including observational studies or randomized controlled trials that investigated the effect of PE or IA on different courses of MS and neuromyelitis optica (NMO). One thousand, three hundred and eighty-three patients were included in the evaluation. Therapy response in relapsing-remitting MS and clinically isolated syndrome was 76.6\% (95\%CI 63.7-89.8\%) in PE- and 80.6\% (95\%CI 69.3-91.8\%) in IA-treated patients. Based on the recent literature, PE and IA may be considered as equal treatment possibilities in patients suffering from acute, glucocorticosteroid-unresponsive MS relapses.
\end{abstract}

Keywords: multiple sclerosis; plasma exchange; immunoadsorption

\section{Introduction}

Multiple sclerosis (MS) is a disease which is defined as an inflammatory condition affecting the central nervous system. Its main course of damage is due to abnormal immune mechanisms, resulting in acute inflammation, demyelination, axonal loss, and the formation of central nervous systemplaques consisting of inflammatory cells [1,2].

The epidemiology of MS differs greatly depending on the geographic regions with a prevalence from high levels in North America and Europe (>100/100,000 inhabitants) to low rates in Eastern Asia and sub-Saharan Africa (2/100,000 population). Women are generally more affected than men [3].

Symptoms that occur with the onset of MS are very unspecific, since MS can affect all regions of the central nervous system and can make it hard for a physician to make an early diagnosis. Symptoms of MS include vision problems with a decreased visual acuity (VA) and a prolonged visual evoked potential (VEP), weakness, fatigue, spasms, ataxia, cognitive dysfunction, or numbness [4]. The occurrence of an optic neuritis in its typical form is considered to be associated with MS. However, it is also regarded as a demyelinating clinically isolated syndrome (CIS) with the risk to convert to MS, especially in the white population [5]. With such a variety of symptoms a thorough medical history and examination is essential to make the right diagnosis of MS. Blood tests, lumbar punctures, magnetic resonance imaging, and evoked potential tests help in the process of differentiating between other 
diseases [6]. Based on the symptoms and the progression of the disease MS is divided in four types: Relapsing-Remitting MS (RRMS), Secondary-Progressive MS (SPMS), Primary-Progressive MS (PPMS), and Progressive-Relapsing MS (PRMS).

MS can be characterized as a T-cell-driven disease with T helper (Th) cells, especially Th-1, Th-2, and Th-17 cells, as the main players in a various inflammatory cascade [7]. For instance, Th- 1 cells are responsible for producing Interferon gamma (IFN $\gamma$ ) and tumor necrosis factor alpha (TNF- $\alpha$ ) [8]. With the secretion of IFNy and TNF- $\alpha$ inflammation can be maintained by inhibiting Th-2 cell differentiation, since Th-2 cells produce anti-inflammatory cytokines like interleukin (IL)-4 and IL-13 [9,10]. Th-17 cells stimulate inflammation via secreting a vast number of various cytokines like IL-17, IL-21, IL-22, and IL-26 [11-13]. As a counterpart regulatory $\mathrm{T}$ (Treg) cells inhibit autoimmune responses [14]. In addition to that immunoglobulins (Ig) (especially IgG) are important in the pathogenesis of MS. Evidence of intrathecal Ig production and oligoclonal IgG bands contribute to the diagnosis of MS. Further differentiation shows various types of specific autoantibodies against myelin in subgroups of patients with MS, e.g., anti-myelin oligo-dendrocyte glycoprotein (anti-MOG) or anti-myelin basic protein (anti-MBP) [15]. Antibody-producing B-cells traveling between CNS, blood, and peripheral lymphatic organs clonally expanded B-cells and aggregated B-cells in meninges corroborate a pathophysiological role of B-cells and/or humoral immune answer in the pathogenesis of MS [16-19].

Based on the myelin protein loss, the geography and extension of plaques, the patterns of oligodendrocyte destruction, and the immunohistopathological evidence of complement activation Lucchinetti et al. described four different immunohistopathological patterns of demyelination in MS [20]. Patterns I and II showed close similarities to T-cell-mediated or T-cell plus antibody-mediated autoimmune encephalomyelitis. Patterns III and IV on the other hand were highly suggestive of a primary oligodendrocyte dystrophy.

Neuromyelitis optica (NMO) on the other hand is described as an idiopathic, severe, demyelinating disease of the central nervous system with the preference to affect the optic nerve and spinal cord. NMO has been considered as a variant of MS. However, with the analysis of clinical, laboratory, immunological, and pathological data the difference to MS is now acknowledged [21].

The treatment regime can be divided in treatment to modify the disease progression and treatment for the acute relapse. In the latter, the administration of high-dose intravenous methylprednisolone (up to $1000 \mathrm{mg}$ daily) over a period of three to five days usually represents the first step in acute MS relapse treatment. A higher second high-dose intravenous methylprednisolone pulse with up to $2 \mathrm{~g}$ can be considered in unresponsive patients after an interval of 2 weeks [22-24]. Glucocorticoids may downregulate cellular cytotoxicity and lead to the death of activated B cells, but they will not modulate tissue destruction or conduction blockade by local antibody deposition [25]. If symptoms persist, the relapse is defined as glucocorticosteroid-unresponsive and immunomodulation by apheresis is recommended. However, several national and international guidelines have no uniform recommendations on using plasma exchange (PE) or immunoadsorption (IA) in this case. The American Society for Apheresis (ASFA) recommends PE for treatment to category II ("apheresis accepted as second-line therapy") and IA for treatment to category III ("optimum role of apheresis therapy is not established") [26]. The American Academy of Neurology also advises the use of PE for adjunctive treatment of relapsing forms of MS (Level B), while IA is not addressed [27,28]. The German guidelines are currently under reconstruction but formerly recommended both procedures as equivalent [29].

In this current issue, we review the use of IA and PE in treating, especially, the acute relapse of MS.

\section{Effects of Apheresis Therapy}

During PE, the patient's plasma, including all plasma proteins, is removed and substituted by human albumin solution or fresh frozen plasma. The concept of IA involves a selective elimination of plasma proteins, e.g., antibodies, while sparing other plasma proteins [30]. Both techniques include an extracorporeal circulation circuit with systemic and/or local anticoagulation, as well as the need of a vascular access. The latter can either be peripheral venous, if individual vascular 
situation allows it, or by a central venous catheter. In IA, a secondary circuit is established in which a defined physico-chemical interaction of selected plasma proteins with a defined matrix should theoretically guarantee selective removal of circulating pathogens. In praxis, a bandwidth of proteins are removed [31,32] which are responsible for therapeutic effects but also possible side effects of IA. These effects differ with regard to used matrix of the adsorber, which physicians should be aware.

The exact mechanism by which apheresis treatment works is actually not fully understood. MS patients may benefit by the immediate removal of plasma antibodies, immune complexes and cytokines, induction of a redistribution of antibodies from the extravascular space, and subsequent immunomodulatory changes [30]. Here, cell types with receptors for immunoglobulins (Fc receptors), such as monocytes, macrophages, and natural killer cells, are especially of interest [25]. Besides effects on humoral immune system, experimental data suggest a reduction of circulating autoantigens and regulatory proteins [32] and induction of a higher relative quantity of Treg to Th17 cells [33], as well as a silencing of cellular autoimmune response [32].

Early active MS lesions with an immunohistopathological type II pattern, which are selectively associated with Ig's and complement deposited along myelin sheaths, predict the best response to apheresis therapy in patients with steroid-unresponsive relapse [34], corroborating the hypothesis of effects on humoral immune response.

\section{Plasma Exchange}

\subsection{Multiple Sclerosis (with Relapsing-Remitting and Progressive MS Sub-Sections)}

The first study comparing the normal therapy regime with PE was performed by Khatri et al. in 1985 and included fifty-four patients with chronic progressive MS [35]. The results showed that patients with the additional PE have a higher improvement rate than patients with a "sham" PE. Following the study of Khatri et al., Weiner et al. enrolled 116 patients in a multicenter, randomized, double-blinded, controlled trial of $11 \mathrm{PE}$ treatments in acute exacerbations of MS [36]. One of the main results showed patients treated with PE to have a significantly enhanced improvement after four weeks. In 1999, a study group of the Mayo Clinic conducted a randomized, sham-controlled, double-blinded study of PE in MS patients with severe neurological deficits after acute relapses, unresponsive to corticosteroids [37]. This study resulted in a moderate to greater improvement in neurological deficits in $42.1 \%$ of patients with true PE versus $5.9 \%$ of patients with sham PE. With the improved work with PE in the clinical setting, a variety of retrospective studies could demonstrate an improvement rate between 59-87.5\% [38-40]. In a large study with 153 patients enrolled, Magana et al. identified 90 patients with moderate to marked functional neurological improvement within 6 months after treatment with PE [41].

An excellent and actual overview on apheresis in progressive MS forms is available in Reference [30]. So far, the ASFA recommends PE for treatment to category III: "Optimum role of apheresis therapy is not established. Decision making should be individualized" [26].

\subsection{Clinically Isolated Syndrome}

More recent studies set their focus not only on the relapsing-remitting and progressive MS sub-sections but also on the clinically isolated syndrome [42-44]. Therapy response rates ranged between $72-76 \%$, therefore achieving a clinical response in the majority of patients.

\subsection{Optic Neuritis}

Studies analyzing the use of PE in the setting of for severe steroid unresponsive optic neuritis were performed by Ruprecht et al. and Deschamps et al. [45,46]. Ruprecht et al. al. demonstrated an improvement of visual acuity in $70 \%$ of patients. Out of these seven patients, three continued to improve with their visual acuity, two remained at a stable state, whereas two patients suffered from worsening symptoms during the follow-ups [46]. 
In the study performed by Deschamps et al., thirty-four patients with a remaining visual acuity of 0.1 were treated with PE. Afterwards, the median visual acuity was 0.8 [45].

Studies on PE are summarized in Table 1 . However, the reader must be aware that the comparability of the studies is limited by the different technical implementation of PE. This varied in frequency, treated plasma volume, and total number of PEs. As a result, the ASFA defined a corridor of technical implementation that recommended treatment of 1-1.5-fold plasma volume per session for a number of 5 to 7 treatments over a period of 10 to 14 days [26].

Table 1. Studies on plasma exchange (PE) in treatment of relapsing-remitting multiple sclerosis (RRMS), clinically isolated syndrome (CIS), progressive MS, isolated optic neuritis, and neuromyelitis optica (NMO). EDSS = Expanded Disability Status Scale.

\begin{tabular}{|c|c|c|c|c|c|c|c|}
\hline \multicolumn{8}{|c|}{ "Relapsing-Remitting Multiple Sclerosis" and "Clinically Isolated Syndrome" } \\
\hline Citation & Year & $n$ & Design & $\begin{array}{c}\text { No. of } \\
\text { Treatments }\end{array}$ & $\begin{array}{l}\text { Treated Plasma } \\
\text { Volume (mL) }\end{array}$ & Outcome & Limitation \\
\hline [36] & 1989 & 116 & $\begin{array}{l}\text { Double-blind, } \\
\text { multi-center, } \\
\text { randomized }\end{array}$ & 11 & n.a. & $\begin{array}{c}\text { Significant } \\
\text { improvement after } 4 \\
\text { weeks }\end{array}$ & $\begin{array}{c}\text { No plasmapheresis } \\
\text { protocol } \\
\text { specifications }\end{array}$ \\
\hline [37] & 1999 & 36 & Double-blind & 7 & 3000 & $\begin{array}{c}\text { Therapy response in } \\
42 \% \text { of patients }\end{array}$ & $\begin{array}{c}\text { Patient collective } \\
\text { with heterogenous } \\
\text { MS-types }\end{array}$ \\
\hline [39] & 2005 & 13 & Retrospective & 5 & 3000 & $\begin{array}{c}\text { Therapy response in } \\
71 \% \text { of patients }\end{array}$ & $\begin{array}{l}\text { Small number of } \\
\text { subjects }\end{array}$ \\
\hline [47] & 2007 & 6 & Retrospective & 4 & $\begin{array}{l}\text { 1.0-fold plasma } \\
\text { volume }\end{array}$ & $\begin{array}{c}\text { Therapy response in } \\
100 \% \text { of patients }\end{array}$ & $\begin{array}{l}\text { Small number of } \\
\text { subjects }\end{array}$ \\
\hline [40] & 2009 & 20 & Retrospective & $3-7$ & $\begin{array}{l}\text { 1.5-fold plasma } \\
\text { volume }\end{array}$ & $\begin{array}{l}\text { Therapy response in } \\
76 \% \text { of patients } \\
\text { regarding visual } \\
\text { acuity }\end{array}$ & $\begin{array}{l}\text { Small number of } \\
\text { subjects }\end{array}$ \\
\hline [38] & 2010 & 4 & Retrospective & 5 & 2750 & $\begin{array}{l}\text { Therapy response in } \\
75 \% \text { of patients }\end{array}$ & $\begin{array}{l}\text { no placebo, Small } \\
\text { number of subjects, } \\
\text { the study was } \\
\text { observational in } \\
\text { character }\end{array}$ \\
\hline$[41]$ & 2011 & 153 & Retrospective & 7 & n.a. & $\begin{array}{c}\text { Therapy response in } \\
59 \% \text { of patients }\end{array}$ & $\begin{array}{c}\text { Patient collective } \\
\text { with heterogenous } \\
\text { MS-types }\end{array}$ \\
\hline [48] & 2013 & 15 & Retrospective & $\geq 7$ & $\begin{array}{l}\text { 1.0-fold plasma } \\
\text { volume }\end{array}$ & $\begin{array}{l}\text { Therapy response in } \\
93.3 \% \text { of patients }\end{array}$ & RRMS + CIS \\
\hline [49] & 2014 & 11 & Retrospective & $\begin{array}{l}\text { Median } 7 \\
\quad(3-8)\end{array}$ & $3000(2200-3500)$ & $\begin{array}{c}\text { Therapy response in } \\
91 \% \text { of patients }\end{array}$ & CIS only \\
\hline [43] & 2015 & 90 & Retrospective & $3-8$ & $\begin{array}{l}\text { 1.0-fold plasma } \\
\text { volume }\end{array}$ & $\begin{array}{c}\text { Therapy response in } \\
72 \% \text { of patients }\end{array}$ & $\begin{array}{c}\text { The lack of a control } \\
\text { group }\end{array}$ \\
\hline [50] & 2016 & 16 & Retrospective & n.a. & 2000 & $\begin{array}{l}\text { Therapy response in } \\
91 \% \text { of patients } \\
\text { regarding visual } \\
\text { evoked potential }\end{array}$ & $\begin{array}{l}\text { Small number of } \\
\text { subjects and a } \\
\text { higher expanded } \\
\text { disability status } \\
\text { scale in patients in } \\
\text { the PE only group }\end{array}$ \\
\hline [51] & 2018 & 46 & Retrospective & $\begin{array}{l}\text { Mean } 7.39 \\
\text { sessions }\end{array}$ & n.a. & $\begin{array}{l}\text { Complete therapy } \\
\text { response in } 41 \% \text { of } \\
\text { patients and partial } \\
\text { therapy response in } \\
39 \% \text { of patients }\end{array}$ & $\begin{array}{c}\text { Patient collective } \\
\text { with heterogenous } \\
\text { MS-types }\end{array}$ \\
\hline [44] & 2019 & 42 & Retrospective & $4-11$ & $\begin{array}{l}\text { Mean } 2930 \\
\text { median } 2000\end{array}$ & $\begin{array}{l}\text { Therapy response in } \\
73 \% \text { of patients }\end{array}$ & $\begin{array}{l}\text { patients without } \\
\text { sufficient follow-up } \\
\text { data had a } \\
\text { significantly higher } \\
\text { patient age and } \\
\text { longer duration of } \\
\text { disease }\end{array}$ \\
\hline [42] & 2019 & 30 & $\begin{array}{l}\text { Double-blind, } \\
\text { randomized, } \\
\text { uni-center }\end{array}$ & On 5 days & $\begin{array}{l}0.69 \pm 0.12 \text {-fold } \\
\text { individual total } \\
\text { plasma volume }\end{array}$ & $\begin{array}{c}\text { Therapy response in } \\
76 \% \text { of patients }\end{array}$ & $\begin{array}{l}\text { Lack of blinding } \\
\text { and small number } \\
\text { of subjects }\end{array}$ \\
\hline
\end{tabular}


Table 1. Cont.

\begin{tabular}{|c|c|c|c|c|c|c|c|}
\hline \multicolumn{8}{|c|}{ "Progressive Multiple Sclerosis" } \\
\hline Citation & Year & $\mathbf{n}$ & Design & $\begin{array}{c}\text { No. of } \\
\text { Treatments }\end{array}$ & $\begin{array}{l}\text { Treated Plasma } \\
\text { Volume (mL) }\end{array}$ & Outcome & Limitation \\
\hline [52] & 1983 & 18 & $\begin{array}{l}\text { Prospective, } \\
\text { randomized }\end{array}$ & $4-5$ & n.a. & $\begin{array}{l}\text { Therapy response in } \\
27.8 \% \text { of patients }\end{array}$ & $\begin{array}{l}\text { Small number of } \\
\text { subjects, no } \\
\text { plasmapheresis } \\
\text { protocol } \\
\text { specifications }\end{array}$ \\
\hline [35] & 1985 & 54 & $\begin{array}{l}\text { Double-blind } \\
\text { controlled }\end{array}$ & 20 & n.a. & $\begin{array}{l}\text { Therapy response in } \\
54 \% \text { of patients }\end{array}$ & $\begin{array}{c}\text { No plasmapheresis } \\
\text { protocol } \\
\text { specifications }\end{array}$ \\
\hline [53] & 1994 & 24 & Prospective & 8 & n.a. & $\begin{array}{l}\text { Therapy response in } \\
87.5 \% \text { of patients }\end{array}$ & $\begin{array}{l}\text { Small number of } \\
\text { subjects, no } \\
\text { plasmapheresis } \\
\text { protocol } \\
\text { specifications }\end{array}$ \\
\hline [41] & 2011 & 10 & Retrospective & 7 & n.a. & $\begin{array}{c}\text { Therapy response in } \\
30 \% \text { of patients }\end{array}$ & $\begin{array}{l}\text { Small number of } \\
\text { subjects }\end{array}$ \\
\hline [54] & 2015 & 6 & $\begin{array}{l}\text { open-label, } \\
\text { single-center } \\
\text { proof of } \\
\text { concept } \\
\text { study }\end{array}$ & 4 & $2000-2500$ & $\begin{array}{l}\text { Therapy response in } \\
66.7 \% \text { of patients }\end{array}$ & $\begin{array}{l}\text { Small number of } \\
\text { subjects }\end{array}$ \\
\hline \multicolumn{8}{|c|}{ "Isolated Optic Neuritis" } \\
\hline Citation & Year & $n$ & Design & $\begin{array}{c}\text { No. of } \\
\text { Treatments }\end{array}$ & $\begin{array}{l}\text { Treated Plasma } \\
\text { Volume (mL) }\end{array}$ & Outcome & Limitation \\
\hline [46] & 2004 & 10 & Retrospective & n.a. & n.a. & $\begin{array}{c}\text { Therapy response in } \\
70 \% \text { of patients }\end{array}$ & $\begin{array}{l}\text { Small number of } \\
\text { subjects }\end{array}$ \\
\hline [55] & 2012 & 23 & Retrospective & 5 & $\sim 3000$ & $\begin{array}{c}\text { Therapy response in } \\
70 \% \text { of patients }\end{array}$ & heterogenous \\
\hline [56] & 2012 & 16 & Retrospective & 5 & $\begin{array}{l}\text { 1.0-fold plasma } \\
\text { volume }\end{array}$ & $\begin{array}{l}\text { Therapy response in } \\
87.5 \% \text { of patients }\end{array}$ & $\begin{array}{l}\text { Small number of } \\
\text { subjects }\end{array}$ \\
\hline [45] & 2016 & 34 & Retrospective & $\begin{array}{l}\text { Median 5, } \\
\text { range 5-10 }\end{array}$ & $\begin{array}{l}1.5 \text {-fold body } \\
\text { mass volume }\end{array}$ & $\begin{array}{l}\text { Therapy response in } \\
56 \% \text { of patients } \\
\text { regarding visual } \\
\text { acuity }\end{array}$ & $\begin{array}{c}\text { The lack of a control } \\
\text { group }\end{array}$ \\
\hline \multicolumn{8}{|c|}{ "Neuromyelitis Optica" } \\
\hline Citation & Year & $n$ & Design & $\begin{array}{c}\text { No. of } \\
\text { Treatments }\end{array}$ & $\begin{array}{l}\text { Treated Plasma } \\
\text { Volume (mL) }\end{array}$ & Outcome & Limitation \\
\hline [57] & 2007 & 6 & Retrospective & $3-5$ & 2000-3000 & $\begin{array}{c}\text { Therapy response in } \\
50 \% \text { of patients }\end{array}$ & $\begin{array}{l}\text { Small number of } \\
\text { subjects }\end{array}$ \\
\hline [58] & 2011 & 5 & Retrospective & $\geq 5$ & $\begin{array}{l}\text { 1.0-fold plasma } \\
\text { volume }\end{array}$ & $\begin{array}{c}\text { Therapy response in } \\
80 \% \text { of patients }\end{array}$ & $\begin{array}{l}\text { Small number of } \\
\text { subjects }\end{array}$ \\
\hline [41] & 2011 & 26 & Retrospective & 7 & n.a. & $\begin{array}{l}\text { Therapy response in } \\
42.3 \% \text { of patients }\end{array}$ & $\begin{array}{l}\text { Historical cohort } \\
\text { study }\end{array}$ \\
\hline [59] & 2013 & 31 & Retrospective & n.a. & n.a. & $\begin{array}{c}\text { Therapy response in } \\
65 \% \text { of patients }\end{array}$ & $\begin{array}{l}\text { No study controlled } \\
\text { treatment regimes }\end{array}$ \\
\hline [60] & 2013 & 15 & Retrospective & 6 & $\begin{array}{c}1.0-1.5 \text {-fold } \\
\text { plasma volume }\end{array}$ & $\begin{array}{c}\text { Therapy response in } \\
78 \% \text { of patients }\end{array}$ & $\begin{array}{c}\text { Small number of } \\
\text { subjects }\end{array}$ \\
\hline [61] & 2016 & 65 & Retrospective & $5-7$ & $\begin{array}{l}\text { 1.5-fold plasma } \\
\text { volume }\end{array}$ & $\begin{array}{c}\text { Therapy response in } \\
65 \% \text { of patients }\end{array}$ & $\begin{array}{l}\text { Selection bias; use } \\
\text { of EDSS scores as } \\
\text { the primary } \\
\text { outcome measure }\end{array}$ \\
\hline [62] & 2017 & 21 & Retrospective & 5 & n.a. & $\begin{array}{c}\text { Therapy response in } \\
81 \% \text { of patients }\end{array}$ & $\begin{array}{l}\text { Use of EDSS scores } \\
\text { as the primary } \\
\text { outcome measure }\end{array}$ \\
\hline [63] & 2018 & 28 & Retrospective & 5 & 1000 & $\begin{array}{l}\text { Therapy response in } \\
42.9 \% \text { of patients }\end{array}$ & $\begin{array}{l}\text { Use of EDSS scores } \\
\text { as the primary } \\
\text { outcome measure }\end{array}$ \\
\hline [64] & 2018 & 29 & Retrospective & $2-7$ & $\begin{array}{l}\text { 1.0-fold plasma } \\
\text { volume }\end{array}$ & $\begin{array}{l}\text { Therapy response in } \\
82.8 \% \text { of patients }\end{array}$ & $\begin{array}{l}\text { Heterogenous } \\
\text { treatment protocols }\end{array}$ \\
\hline [65] & 2018 & 9 & Retrospective & 7 & $\begin{array}{c}\text { 1.0-fold plasma } \\
\text { volume }\end{array}$ & $\begin{array}{l}\text { Therapy response in } \\
75 \% \text { of patients }\end{array}$ & $\begin{array}{c}\text { Small number of } \\
\text { subjects }\end{array}$ \\
\hline
\end{tabular}


Table 1. Cont.

\begin{tabular}{|c|c|c|c|c|c|c|c|}
\hline \multicolumn{8}{|c|}{ "Neuromyelitis Optica" } \\
\hline Citation & Year & $n$ & Design & $\begin{array}{l}\text { No. of } \\
\text { Treatments }\end{array}$ & $\begin{array}{l}\text { Treated Plasma } \\
\text { Volume (mL) }\end{array}$ & Outcome & Limitation \\
\hline [66] & 2018 & 5 & Retrospective & $5(3-7)$ & $\begin{array}{l}\text { 1.0-fold plasma } \\
\text { volume }\end{array}$ & $\begin{array}{c}\text { Therapy response in } \\
80 \% \text { of patients }\end{array}$ & $\begin{array}{l}\text { Small number of } \\
\text { subjects }\end{array}$ \\
\hline [67] & 2018 & 146 & Retrospective & $\geq 3$ & n.a. & $\begin{array}{c}\text { Therapy response in } \\
86 \% \text { of patients }\end{array}$ & $\begin{array}{l}\text { Heterogenous } \\
\text { treatment protocols }\end{array}$ \\
\hline$[68]$ & 2019 & 15 & Retrospective & $2-3$ & n.a & $\begin{array}{c}\text { Therapy response in } \\
100 \% \text { of patients }\end{array}$ & $\begin{array}{c}\text { Small number of } \\
\text { subjects }\end{array}$ \\
\hline
\end{tabular}

\section{Immunoadsorption}

\subsection{Multiple Sclerosis (with Relapsing-Remitting and Progressive MS Sub-Sections)}

IA was firstly introduced in the treatment of MS by de Andres et al. in 2000 [69]. They managed a prompt and unequivocal clinical response with a parallel decrease in IgG, fibrinogen, and C3 complement plasma levels in all three patients treated with IA. In the following years, retrospective studies confirmed the initial results of de Andres et al., showing improvement rates from $85-88.3 \%$ in MS patients receiving an IA therapy [70,71].

\subsection{Clinically Isolated Syndrome}

Studies incorporating patients with clinically isolated syndrome showed marked to moderate clinical response with a total gain of function in $66-100 \%$ of patients after treatment with immunoadsorption [42,72].

\subsection{Neuromyelitis Optica}

The first prospective study investigating effects of IA therapy in patients with MS with steroid-refractory optical neuritis showed an improvement of the mean visual acuity in 8 from 11 patients at day $180 \pm 10$ after IA [32]. A more recent study confirmed the efficacy and good tolerance of IA in relapses of MS patients with failure to respond to a steroid pulse therapy adequately. Moreover, the study established IA as first-line relapse treatment during pregnancy and breastfeeding [73].

The most commonly used column was a tryptophane-linked polyvinyl alcohol adsorber, but also a Sepharose-conjugated sheep antibodies to human IgG, as well as protein A column, have been used. Table 2 gives an overview about IA-studies in acute relapses of MS.

\section{Plasma Exchange vs. Immunoadsorption}

\subsection{Multiple Sclerosis (with Relapsing-Remitting and Progressive MS Sub-Sections)}

Recently, studies have been designed to compare the efficacy of PE versus IA. The most impressive work is that of Dorst et al. [42]. Sixty-one patients with acute relapse of multiple sclerosis or clinically isolated syndrome and without complete clinical remission of symptoms after at least one cycle of high-dose intravenous methylprednisolone were randomly assigned to receive IA $(n=31)$ or PE $(n=30)$. In the IA group (using a protein A adsorber), the 2.0-fold individual total plasma volume was processed on day 1, and the 2.5-fold on days 2-5. In the PE group, $2 \mathrm{~L}$ of plasma (corresponding to the $0.69 \pm 0.12$-fold individual total plasma volume) were removed each day and substituted by $5 \%$ human albumin solution. The median improvement of Multiple Sclerosis Functional Composite after 4 weeks compared to baseline was 0.385 (interquartile range (IQR) $0.200-0.675 ; p<0.001$ ) in the IA group and 0.265 (IQR 0.100-0.408; $p<0.001$ ) in the PE group. Improvement in the IA group was significantly larger $(p=0.034)$ compared to PE. Response rates after 4 weeks were $86.7 \%$ in the IA group and $76.7 \%$ in the PE group. One deep venous thrombosis occurred in each group. One limitation in interpretation 
of this study, however, is that the apheresis dose applied was quite different in the two treatment arms and the observation period was relatively short.

Hohenstein et al. reported the successful use of IA with regenerating adsorbers in MS patients as a single center experience [78]. Faissner et al. compared PE and IA directly and demonstrated in a grouped analysis of patients treated with combined PE/ IA, PE, or IA alone, that all groups presented with a better result of visual evoked potentials, providing a valid treatment option in steroid-refractory MS-relapses [50].

\subsection{Clinically Isolated Syndrome}

Dorst et al. [42] also enrolled patients suffering from a clinically isolated syndrome in their recent study. The results are discussed above.

\subsection{Neuromyelitis Optica}

In a small cohort study, Faissner et al. showed equivalent results treating patients with neuromyelitis optica spectrum disorder with IA instead of PE, constituting IA as a valid therapeutic option [77]. Studies of our own also indicate PE and IA to be of equal efficacy and treatment safety $[44,79]$. We assessed 140 adult patients treated with PE $(n=73)$ or IA $(n=67)$ in steroid refractory multiple sclerosis or neuromyelitis optica. During our studies, we became aware of the fact that differences in body-mass-index, duration of disease, number of treatments, vascular access and treated plasma volumes between IA - and PE cohorts are a main concern for possible bias in the assessment of IA and PE as a treatment for MS patients. We also performed a retrospective single-center cohort study of pediatric patients with inflammatory CNS demyelinating disorders showing excellent tolerance and favorable outcomes of PE and IA in all pediatric patients [31].

\section{Meta-Analysis on Apheresis Effects on Demyelinating Diseases}

\subsection{Search Strategy and Inclusion Criteria}

A systematic search was performed using Medline and Cochrane Library with combinations of the search terms "plasma exchange" OR "immunoadsorption" in combination with the terms "multiple sclerosis" OR "clinical isolated syndrome" OR "neuromyelitis optica" between 1980 and January 2020. Reports were screened independently for relevance based on title and abstract content by two authors (M.L. and M.J.K.). Randomized-controlled trials, as well as prospective cohort studies and retrospective studies and case series, were included if sufficient information on therapy response of PE or IA was provided. Studies with heterogeneous mixing MS, CIS, and/or NMO patients regarding therapy response were excluded if the treatment response was not specified separately in the individual indications. Moreover, case series with a case number less than five in the individual indication were also excluded. It should be mentioned as a limitation that there was no uniform definition of the term "therapy response" in the selected works and, with the exception of a few studies, the majority was retrospective data collection. The flow chart in Figure 1 summarizes the selection of studies in the meta-analysis. 


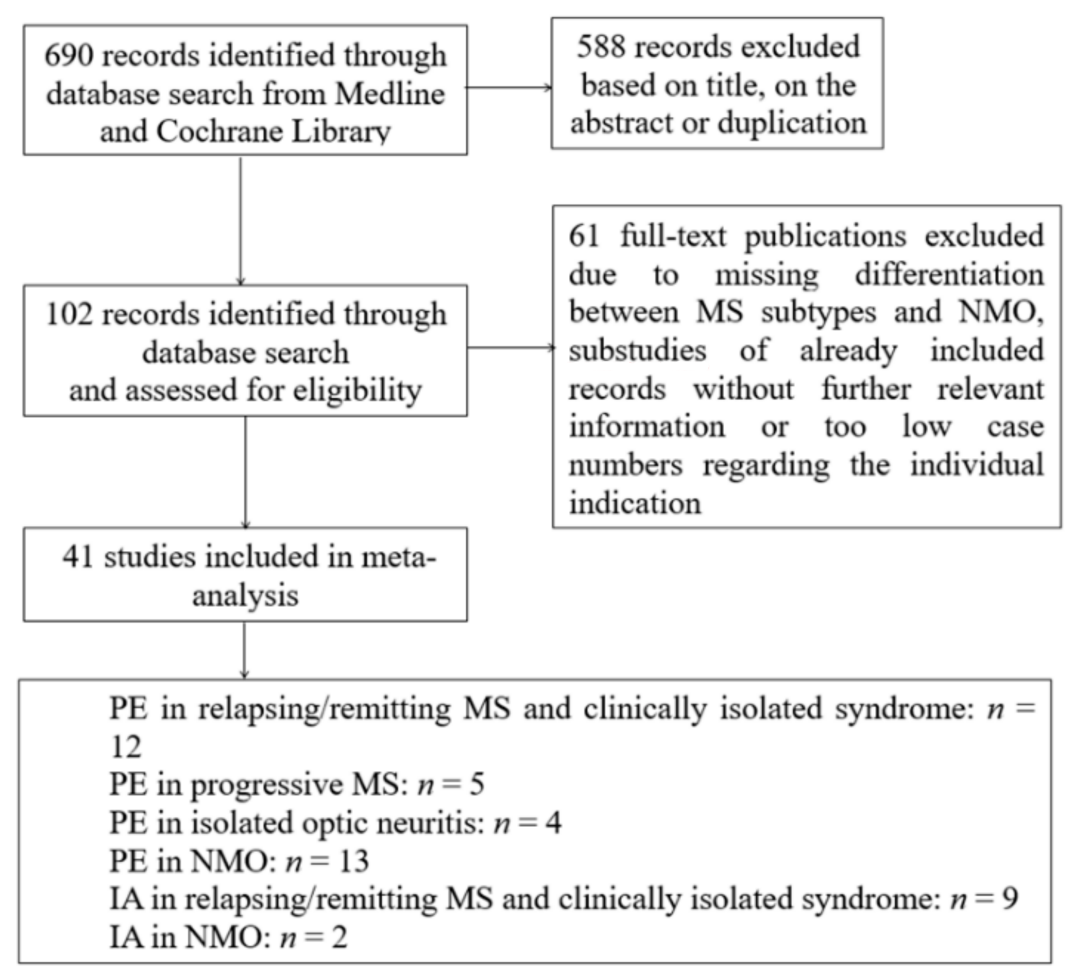

Figure 1. Flow chart of study selection. $\mathrm{MS}=$ multiple sclerosis, $\mathrm{NMO}=$ neuromyelitis optica, $\mathrm{PE}=$ plasma exchange, $\mathrm{IA}=$ immunoadsorption.

\subsection{Statistical Analysis}

Analysis was performed using RevMan V.5.3 (Nordic Cochrane Centre, Copenhagen, Denmark, the Cochrane Collaboration, 2014). Data were quantitatively synthesized by an inverse-variance-weighted meta-analysis using a random-effect model because of the presence of heterogeneity. The normal approximation interval $(\operatorname{sqrt}(p(1-p) / n))$ was used to generate the confidence interval for the therapy response rate. For studies where the normal approximation interval was zero, the confidence interval was set to one to calculate the random effect model. The $95 \%$ normal approximation confidence interval is provided in the meta-analyses.

\section{Results}

With the present search strategy and assessment of full-texts 690 studies, 40 observational and 1 randomized with a total of 1.383 patients could be analyzed. Figure 1 shows the flow chart of study selection.

Effects of PE can be summarized as follows: in relapsing-remitting MS and clinically isolated syndrome (12 studies and 398 patients) therapy response of 76.6\% (95\%CI 63.7-89.8\%) (Figure 2A), in progressive MS (5 studies and 112 patients) therapy response of $53.9 \%(95 \% \mathrm{CI} 29.5-78.4)$ (Figure $2 \mathrm{~B})$, in isolated optic neuritis (4 studies and 83 patients) therapy response of 71.5\% (95\%CI 56.4-86.6\%) (Figure 2C), and in NMO (13 studies and 401 patients) therapy response of 72.5\% (95\%CI 61.0-83.9\%) (Figure 2D).

Effects of IA can be summarized as follows: in relapsing-remitting MS and clinically isolated syndrome (9 studies and 352 patients), therapy response of 80.6\% (95\%CI 69.3-91.8\%) (Figure 2E); and in NMO (2 studies and 37 patients), therapy response of 100\% (95\%CI 98.6-101.4\%) (Figure 2F). 


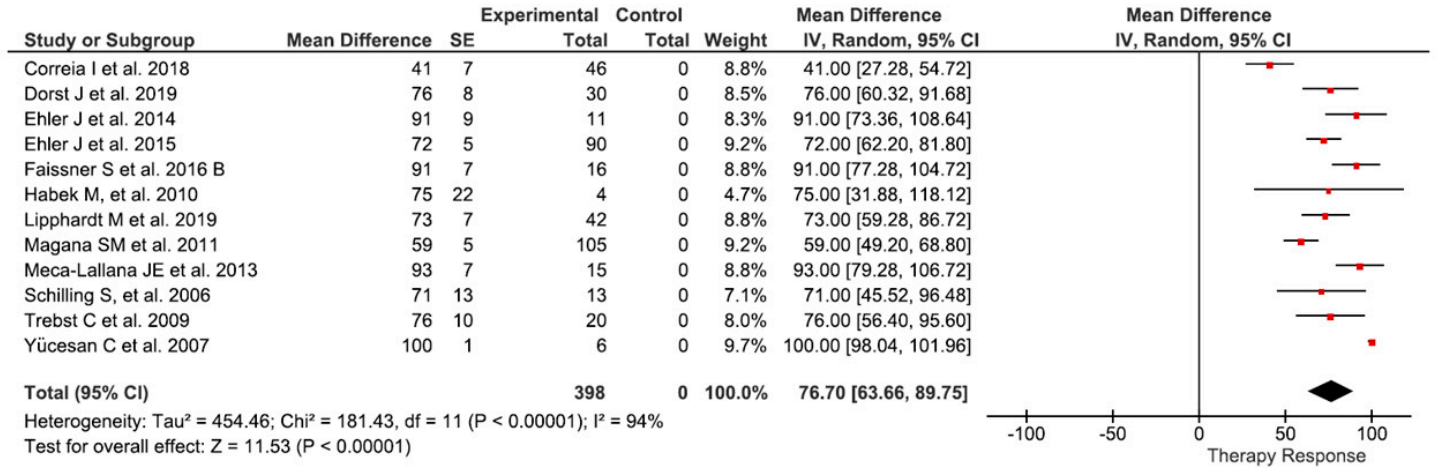

(A)

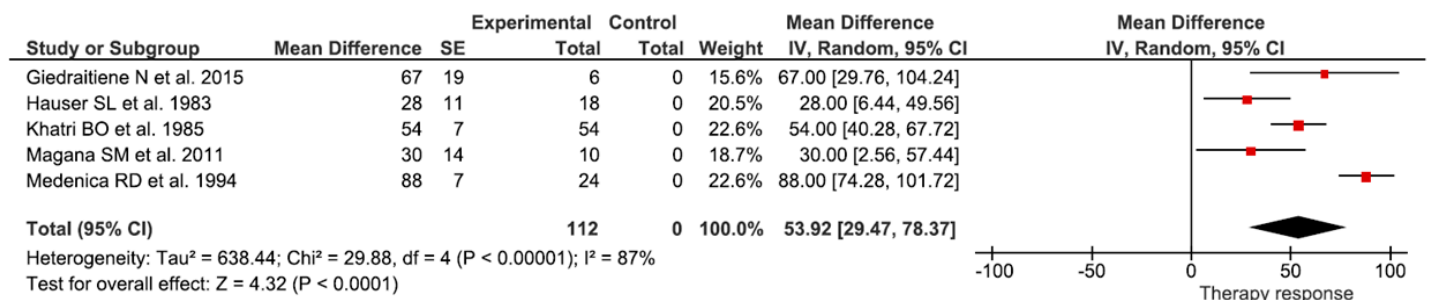

(B)

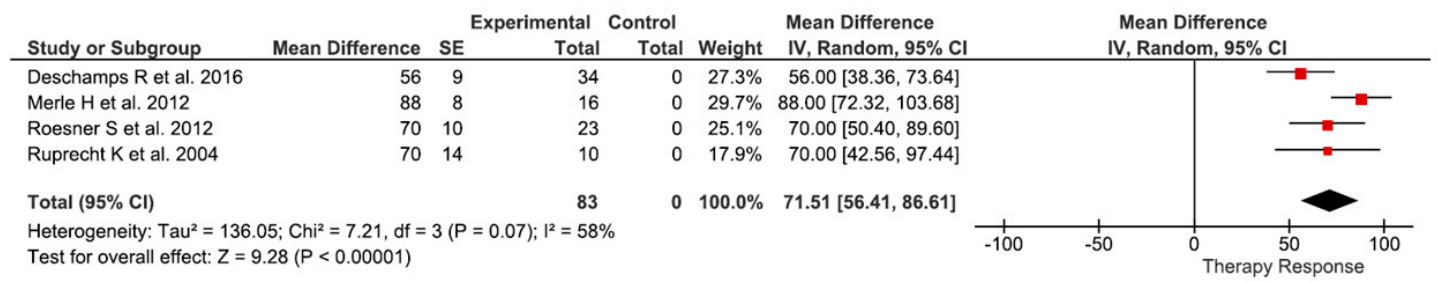

(C)

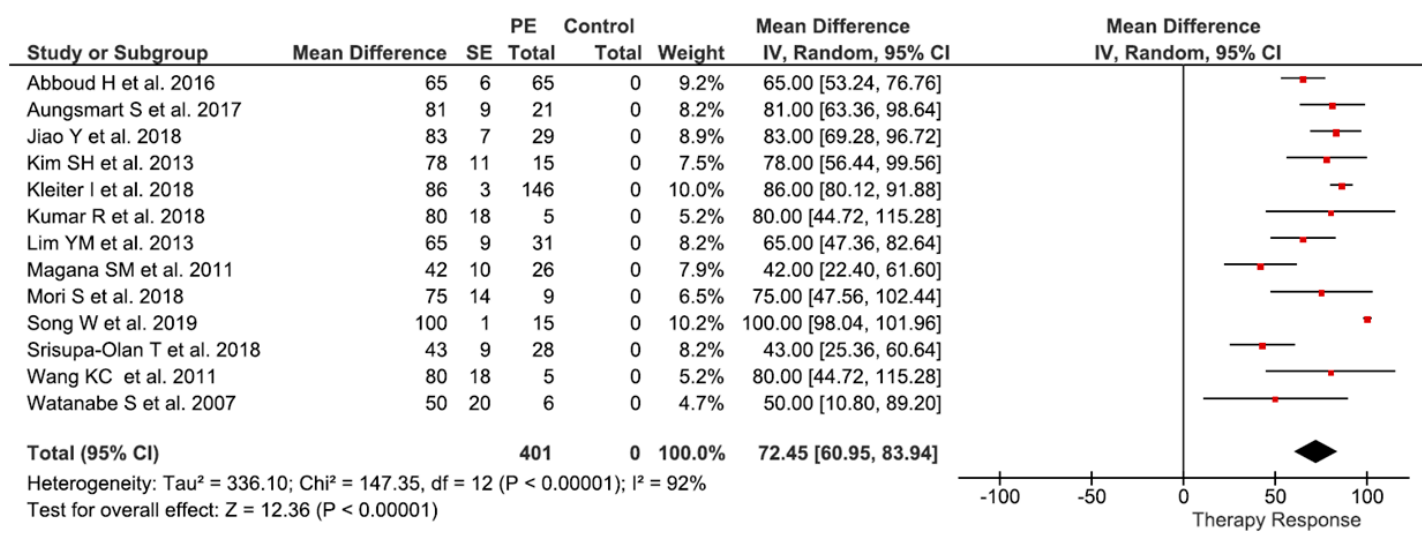

(D)

Figure 2. Cont. 


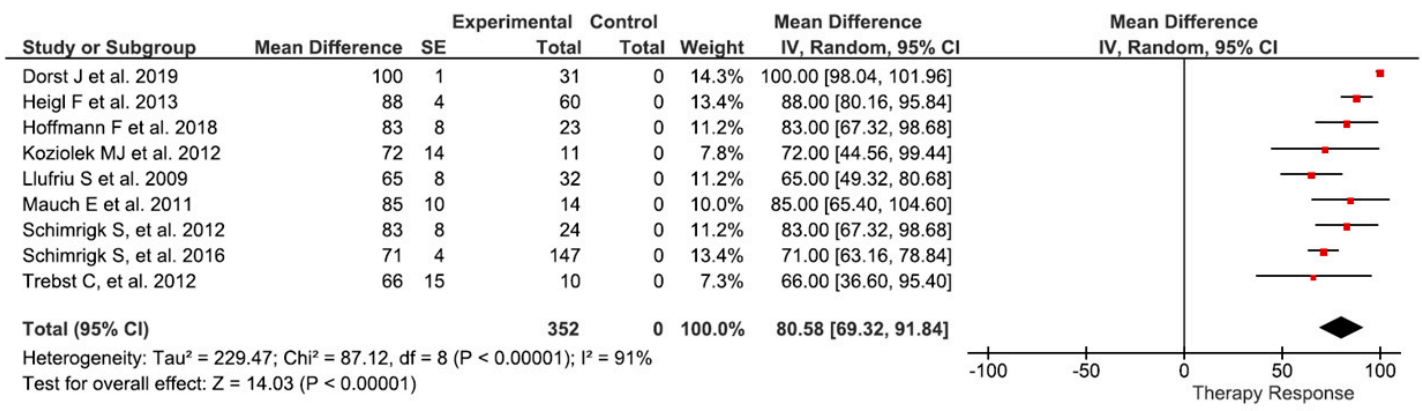

(E)

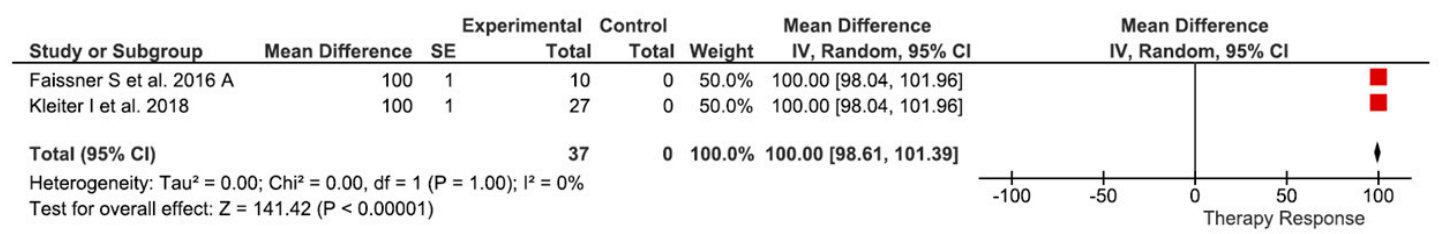

(F)

Figure 2. The $95 \%$ normal approximation confidence interval is provided in the meta-analyses. The given SE correspond to normal approximation confidence interval $(\operatorname{sqrt}(p(1-p) / n))$. (A) Effects of PE in RRMS and CIS. (B) Effects of PE in PMS. (C) Effects of PE in opticus neuritis. (D) Effects of PE in NMO. (E) Effects of IA in RRMS and CIS. (F) Effects of IA in NMO. RRMS = relapsing-remitting multiple sclerosis, CIS = clinically isolated syndrome, $\mathrm{PMS}=$ progressive multiple sclerosis, $\mathrm{SE}=$ standard error, IV = instrumental variables. Figure 2A: Correia et al. [51], Dorst et al. [42], Ehler et al. [49], Ehler at al. [43], Faissner et al. [50], Habek et al. [38], Lipphardt et al. [44], Magana et al. [41], Meca-Lallana et al. [48], Schilling et al. [39], Trebst et al. [40], Yücesan et al. [47]. Figure 2B: Giedraitiene et al. [54], Hauser et al. [52], Khatri et al. [35], Magana et al. [41], Medenica et al. [53]. Figure 2C: Deschamps et al. [45], Merle et al. [56], Roesner et al. [55], Ruprecht et al. [46]. Figure 2D: Abboud et al. [61], Aungsmart et al. [62], Jiao et al. [64], Kim et al. [60], Kleiter et al. [67], Kumar et al. [66], Lim et al. [59], Magana et al. [41], Mori et al. [65], Song et al. [68], Srisupa-Olan et al. [63], Wang et al. [58], Watanabe et al. [57]. Figure 2E: Dorst et al. [42], Heigl et al. [70], Hoffmann et al. [73], Koziolek et al. [32], Llufriu et al. [80], Mauch et al. [71], Schimrigk et al. [75], Schimrigk et al. [76], Trebst et al. [72]. Figure 2F: Faissner et al. [77], Kleiter et al. [67].

Table 2. Studies on immunoadsorption in treatment of relapsing-remitting multiple sclerosis (RRMS), clinically isolated syndrome (CIS) and neuromyelitis optica (NMO).

\begin{tabular}{|c|c|c|c|c|c|c|c|c|}
\hline \multicolumn{9}{|c|}{ "RRMS" and "CIS" } \\
\hline Citation & Year & $n$ & Design & $\begin{array}{c}\text { No. of } \\
\text { Treatments }\end{array}$ & $\begin{array}{c}\text { Treated } \\
\text { Plasma } \\
\text { Volume }(\mathrm{mL})\end{array}$ & Matrix of Adsorber & Outcome & Limitation \\
\hline [74] & 2005 & 12 & Prospective & 14 & $\begin{array}{l}1.5 \text {-fold } \\
\text { plasma } \\
\text { volume }\end{array}$ & $\begin{array}{l}\text { Sepharose-conjugated } \\
\text { sheep antibodies to } \\
\text { human } \\
\text { immunoglobulin (IgG) }\end{array}$ & $\begin{array}{l}\text { No significant } \\
\text { therapy response }\end{array}$ & $\begin{array}{l}\text { small number of } \\
\text { subjects and patient } \\
\text { collective with } \\
\text { heterogenous } \\
\text { MS-types }\end{array}$ \\
\hline [71] & 2011 & 14 & Retrospective & $5-6$ & n.a. & Tryptophan & $\begin{array}{l}\text { Therapy response } \\
\text { in } 85 \% \text { of patients }\end{array}$ & $\begin{array}{l}\text { small number of } \\
\text { subjects } \\
\text { small number of }\end{array}$ \\
\hline [75] & 2012 & 24 & Retrospective & $\begin{array}{c}\text { Mean 5 } \\
\text { (range 3-6) }\end{array}$ & $2000-2500$ & Tryptophan & $\begin{array}{l}\text { Therapy response } \\
\text { in } 83 \% \text { of patients }\end{array}$ & $\begin{array}{l}\text { subjects and patient } \\
\text { collective with } \\
\text { heterogenous } \\
\text { MS-types }\end{array}$ \\
\hline
\end{tabular}


Table 2. Cont.

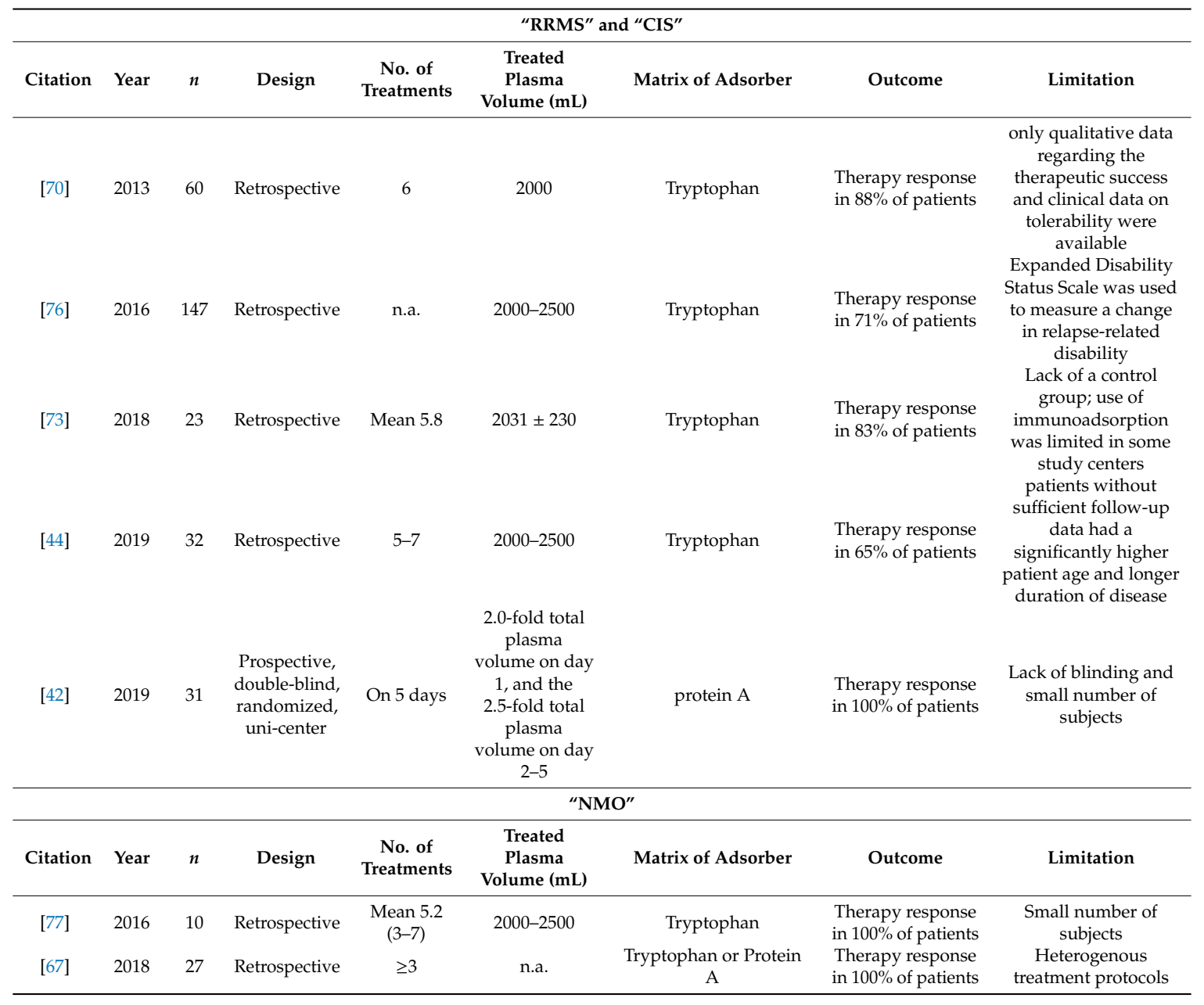

\section{Safety Profile}

\subsection{General}

Another important fact to consider is the treatment safety. The noted rates of side effects during those apheresis treatments are very heterogeneous. In the literature one can find complication rates from $4.2 \%$ until 25.6\% [81-84]. In 2011, Köhler et al. postulated lower side effects using IA in patients suffering from myasthenia gravis [85]. They claim that a possible reason for the difference was due to the absence of albumin-substitution. Zoellner et al. designed a study to investigate the fibrinogen level and the occurrence of bleeding complications [86]. They demonstrated IA to have a lower degree of fibrinogen reduction as PE. Bleeding complications occurred in $1.3-3.1 \%$ of treatments. Schneider-Gold et al. reported allergic reactions, hypocoagulability, and bronchorespiratory infections with a significant higher frequency in the PE-only group as compared to the IA-only group or the both combined [87].

\subsection{Multiple Sclerosis (with Relapsing-Remitting and Progressive MS Sub-Sections) and Clinically Isolated Syndrome}

In the recent study performed by Dorst et al. [42], a general well tolerance was observed with 5 mild infections in the PE group and 4 mild allergic reactions in the IA group. Furthermore, courses of anemia and thrombocytopenia were documented with anemia being more frequent in the PE group and thrombocytopenia being more frequent in the IA group. 


\subsection{Multiple Sclerosis (with Relapsing-Remitting and Progressive MS Sub-Sections) and Neuromyelitis Optica}

In our studies the complication rate was about $3.7 \%$ in over 780 apheresis cycles. Furthermore, we could not detect any differences regarding the safety profile of IA versus PE [44,79].

All in all, both IA and PE have a high tolerability regarding the safety profile. It should be added that the majority of the documented side effects are to be considered as mild. However, the use of IA and PE should be reserved to specialized centers familiar with technical procedure and experienced with this specialized patient population to ensure a high quality of treatment with low complication rates.

\section{Treatment Predictors}

\subsection{General}

One major predicting factor is the time to initiate apheresis treatment. Early initiation of apheresis correlates with a higher response rate as was shown by several study groups $[44,60,80,88]$. In the onset of sudden hearing loss, the early initiation of apheresis treatment was also beneficial [89].

Comparing the cumulative corticosteroid doses in apheresis-responders versus non-responders, no significant difference was shown, which makes a synergistic effect of apheresis and corticosteroids unlikely [44].

\subsection{Multiple Sclerosis (with Relapsing-Remitting and Progressive MS Sub-Sections)}

Magana et al. postulated the duration of the disease and preserved deep tendon reflexes as important clinical predictors [41]. A different approach was followed by the study group of Stork et al., who conducted a single-center cohort study with 69 MS patients, evaluating treatment response in relation to histopathologically defined immunopathological patterns of MS [34]. As early active demyelinating MS lesions can be divided in 3 different immunopathological patterns of demyelination, Stork et al. demonstrated that patients with pattern 1 and 2 are most likely to benefit from apheresis treatment, especially in patients with pattern 2 who show signs of a humoral immune response in particular. Patients with pattern 3 most likely do not benefit from apheresis treatment. During our studies, we also became aware of the fact that patients having a good response to apheresis treatment were significantly younger than non-responders [44]. This observation may be due to a decrease in remyelination efficiency, as proposed by Sim et al. [90]. A gender-related treatment benefit towards the female gender was identified in sub-groups of MS patients [44,91].

\subsection{Neuromyelitis Optica}

In a large study performed by Kleiter et al., it was shown that PE or IA exerts a better recovery from acute relapses in patients suffering from neuromyelitis optica if they had isolated myelitis [92]. More recent studies focused on the plasma anti-aquaporin- 4 immunoglobulin $\mathrm{G}$ antibody as a positive predictor for treatment success with PE or IA in patients suffering from neuromyelitis optica spectrum disorder [12]. In both studies, particularly, patients with a positive anti-aquaporin-4 immunoglobulin $\mathrm{G}$ antibody responded well to the treatment with PE and IA. In addition to that, no advantage was revealed for either PE or IA. The disease specificity of anti-aquaporin-4 immunoglobulin G antibody is almost at $100 \%$ and clinical studies with immunohistochemical evidence suggest that this antibody plays a central role in the pathogenesis of neuromyelitis optica spectrum disorder [93].

These predictors can thus be summarized according to various variables. Table 3 provides a compilation. 
Table 3. Predictors of apheresis response. EDSS = Expanded Disability Status Scale; MRI = magnetic resonance imaging. ${ }^{*}$ Pediatric patients only.

\begin{tabular}{|c|c|c|c|}
\hline \multicolumn{4}{|c|}{ "Multiple Sclerosis" (with Relapsing-Remitting and Progressive MS Sub-Sections) } \\
\hline Classification & Predictor & Citation & Meaning \\
\hline Clinical signs and & EDSS $\leq 5$ & [43] & Indicates good apheresis response \\
\hline symptoms & Preserved deep tendon reflexes & [41] & Indicates good apheresis response \\
\hline Demooraphics & Younger age & {$[44]$} & Indicates good apheresis response \\
\hline Demographics & Female & {$[37,91]$} & Indicates good apheresis response \\
\hline Histological & Gadolinium positive MRI lesions & [43] & Indicates good apheresis response \\
\hline classification and & Histological type 1 and 2 pattern & [34] & Indicates good apheresis response \\
\hline localization & Histological type 3 pattern & [34] & Indicates poor apheresis response \\
\hline & No disease modifying drugs & [43] & Indicates good apheresis response \\
\hline Pre-treatment & Short duration of disease & [41] & Indicates good apheresis response \\
\hline \multicolumn{4}{|c|}{ "Neuromyelitis Optica" } \\
\hline Classification & Predictor & Citation & Meaning \\
\hline $\begin{array}{c}\text { Histological } \\
\text { classification and } \\
\text { localization }\end{array}$ & Isolated myelitis & [85] & Indicates good apheresis response \\
\hline Laboratory values & Anti-aquaporin-4 $\mathrm{IgG}$ positive & [12] & Indicates good apheresis response \\
\hline \multicolumn{4}{|c|}{ "Mixed" } \\
\hline Classification & Predictor & Citation & Meaning \\
\hline Apheresis & Early initiation & {$[44,60,80,88]$} & Indicates good apheresis response \\
\hline $\begin{array}{l}\text { Clinical signs and } \\
\text { symptoms }\end{array}$ & $\begin{array}{l}\text { Lower baseline scores on the EDSS, } \\
\text { visual outcome, and gait scales }\end{array}$ & {$[94]^{*}$} & Indicates good apheresis response \\
\hline Pre-treatment & Cumulative corticosteroid doses & {$[44]$} & Irrelevant for apheresis response \\
\hline
\end{tabular}

\section{Therapeutic Efficacy and Time Course}

As for the time course of the therapeutic effect, the current literature agrees on regular neurological follow-ups after 6 months, manifesting a continuous and maximal clinical effect of the apheresis treatment $[41,44,60,80]$. Therapeutic effects over such a long period of time suggest immunomodulatory actions of apheresis rather than antibody removal on its own [95]. Those immunomodulatory actions happen most likely at the level of Th-cells and CNS-associated proteins, like the myelin basic protein. The prolonged therapeutic effect can be thought of as a clinical correlate of the immunomodulatory components of therapeutic apheresis. Furthermore, the duration of the apheresis induced therapeutic effect can be involved in the treatment process of initiating or changing disease-modifying drugs.

\section{Conclusions}

The focus of this current issue is the use and comparison of immunoadsorption and plasma exchange in the treatment of multiple sclerosis with the main concern of acute relapses.

Based on the studies of the current literature and performance of a meta-analysis, including 690 studies, 40 observational and 1 randomized with a total of 1383 patients, plasma exchange and immunoadsorption are treatment options of equal effectivity for acute glucocorticosteroid-unresponsive multiple sclerosis relapses.

For the meta-analysis randomized-controlled trials, prospective cohort studies, retrospective studies, and case series with sufficient information on therapy response of plasma exchange or immunoadsorption were included. Studies with heterogeneous mixing multiple sclerosis, clinically isolated syndrome, and/or neuromyelitis optica patients regarding therapy response were not included if the treatment response was not specified separately in the individual indications.

Plasma exchange has a therapy response of $76.6 \%$ in relapsing-remitting multiple sclerosis (RRMS) and clinically isolated syndrome (CIS), 53.9\% in progressive multiple sclerosis (PMS), $71.5 \%$ in isolated optic neuritis, and $72.5 \%$ in neuromyelitis optica (NMO). Immunoadsorption (IA) has a therapy 
response of $80.6 \%$ in relapsing-remitting multiple sclerosis and clinically isolated syndrome and $100 \%$ in neuromyelitis optica.

Early treatment initiation with a median of 2-3 weeks and a patient age below 50 are considered to be beneficial regarding a treatment success. In addition to that, a treatment count of 5 to 7 with one plasma volume is also beneficial for treatment success, whereas patients suffering from progressive multiple sclerosis have a lower beneficial rate of apheresis therapy. Both immunoadsorption and plasma exchange have a high safety profile and a high tolerability regarding side effects.

Nevertheless, data situation is too heterogeneous regarding procedures and technical implementation to be finally assessed.

Author Contributions: Conceptualization, M.J.K.; Formal analysis, M.W.; Methodology, M.W.; Supervision, M.J.K.; Validation, M.L. and M.J.K.; Visualization, M.L.; Writing—original draft, M.L.; Writing—review \& editing, M.W. and M.J.K. All authors have read and agreed to the published version of the manuscript.

Acknowledgments: This publication is dedicated to the work of G. A. Müller, who always promoted apheresis therapy during his time as a full professor at the chair of Nephrology Göttingen, Germany.

Conflicts of Interest: The authors declare no conflict of interest.

\section{Abbreviations}

$\begin{array}{ll}\text { ASFA } & \text { American society for apheresis } \\ \text { CIS } & \text { Clinical isolated syndrome } \\ \text { Ig } & \text { Immunoglobulin } \\ \text { IL } & \text { Interleukin } \\ \text { IFN } \gamma & \text { Interferon gamma } \\ \text { NMO } & \text { Neuromyelitis optica } \\ \text { MS } & \text { Multiple Sclerosis } \\ \text { PE } & \text { Plasma exchange } \\ \text { PPMS } & \text { Primary-Progressive MS } \\ \text { PRMS } & \text { Progressive-Relapsing MS } \\ \text { RRMS } & \text { Relapsing remitting MS } \\ \text { SPMS } & \text { Secondary-Progressive MS } \\ \text { Th } & \text { T helper } \\ \text { Treg } & \text { T regulatory } \\ \text { TNF- } \alpha & \text { Tumor necrosis factor alpha } \\ \text { VA } & \text { Visual acuity } \\ \text { VEP } & \text { Visual evoked potential }\end{array}$

\section{References}

1. Brucklacher-Waldert, V.; Stuerner, K.; Kolster, M.; Wolthausen, J.; Tolosa, E. Phenotypical and functional characterization of T helper 17 cells in multiple sclerosis. Brain A J. Neurol. 2009, 132 Pt 12, 3329-3341. [CrossRef]

2. Loma, I.; Heyman, R. Multiple sclerosis: Pathogenesis and treatment. Curr. Neuropharmacol. 2011, 9, $409-416$. [CrossRef]

3. Leray, E.; Moreau, T.; Fromont, A.; Edan, G. Epidemiology of multiple sclerosis. Rev. Neurol. 2016, 172, 3-13. [CrossRef]

4. Compston, A.; Coles, A. Multiple sclerosis. Lancet 2008, 372, 1502-1517. [CrossRef]

5. Toosy, A.T.; Mason, D.F.; Miller, D.H. Optic neuritis. Lancet Neurol. 2014, 13, 83-99. [CrossRef]

6. Thompson, A.J.; Banwell, B.L.; Barkhof, F.; Carroll, W.M.; Coetzee, T.; Comi, G.; Correale, J.; Fazekas, F.; Filippi, M.; Freedman, M.S.; et al. Diagnosis of multiple sclerosis: 2017 revisions of the McDonald criteria. Lancet Neurol. 2018, 17, 162-173. [CrossRef]

7. Correale, J.; Villa, A. Role of CD8+ CD25+ Foxp3+ regulatory T cells in multiple sclerosis. Ann. Neurol. 2010, 67, 625-638. [CrossRef] 
8. Schoenborn, J.R.; Wilson, C.B. Regulation of interferon-gamma during innate and adaptive immune responses. Adv. Immunol. 2007, 96, 41-101.

9. Minty, A.; Chalon, P.; Derocq, J.M.; Dumont, X.; Guillemot, J.C.; Kaghad, M.; Labit, C.; Leplatois, P.; Liauzun, P.; Miloux, B.; et al. Interleukin-13 is a new human lymphokine regulating inflammatory and immune responses. Nature 1993, 362, 248-250. [CrossRef]

10. Zhu, J.; Paul, W.E. CD4 T cells: Fates, functions, and faults. Blood 2008, 112, 1557-1569. [CrossRef]

11. Ghasemi, N.; Razavi, S.; Nikzad, E. Multiple Sclerosis: Pathogenesis, Symptoms, Diagnoses and Cell-Based Therapy. Cell J. 2017, 19, 1-10.

12. Nishimura, H.; Enokida, H.; Sakamoto, T.; Takahashi, T.; Hayami, H.; Nakagawa, M. Immunoadsorption plasmapheresis treatment for the recurrent exacerbation of neuromyelitis optica spectrum disorder with a fluctuating anti-aquaporin-4 antibody level. J. Artif. Organs 2018, 21, 378-382. [CrossRef]

13. Ouyang, W.; Kolls, J.K.; Zheng, Y. The biological functions of Thelper 17 cell effector cytokines in inflammation. Immunity 2008, 28, 454-467. [CrossRef]

14. Lee, G.R. The Balance of Th17 versus Treg Cells in Autoimmunity. Int. J. Mol. Sci. 2018, 19, 730. [CrossRef]

15. Egg, R.; Reindl, M.; Deisenhammer, F.; Linington, C.; Berger, T. Anti-MOG and anti-MBP antibody subclasses in multiple sclerosis. Mult. Scler. J. 2001, 7, 285-289. [CrossRef]

16. Dendrou, C.A.; Fugger, L.; Friese, M.A. Immunopathology of multiple sclerosis. Nat. Rev. Immunol. 2015, 15, 545-558. [CrossRef]

17. Grigoriadis, N.; van Pesch, V. A basic overview of multiple sclerosis immunopathology. Eur. J. Neurol. 2015, 22, 3-13. [CrossRef]

18. Howell, O.W.; Reeves, C.A.; Nicholas, R.; Carassiti, D.; Radotra, B.; Gentleman, S.M.; Serafini, B.; Aloisi, F.; Roncaroli, F.; Magliozzi, R.; et al. Meningeal inflammation is widespread and linked to cortical pathology in multiple sclerosis. Brain A J. Neurol. 2011, 134, 2755-2771. [CrossRef]

19. Stern, J.N.H.; Yaari, G.; Vander Heiden, J.A.; Church, G.; Donahue, W.F.; Hintzen, R.Q.; Huttner, A.J.; Laman, J.D.; Nagra, R.M.; Nylander, A.; et al. B cells populating the multiple sclerosis brain mature in the draining cervical lymph nodes. Sci. Transl. Med. 2014, 6, 248ra107. [CrossRef]

20. Lucchinetti, C.; Bruck, W.; Parisi, J.; Scheithauer, B.; Rodriguez, M.; Lassmann, H. Heterogeneity of multiple sclerosis lesions: Implications for the pathogenesis of demyelination. Ann. Neurol. 2000, 47, 707-717. [CrossRef]

21. Wingerchuk, D.M.; Lennon, V.A.; Lucchinetti, C.F.; Pittock, S.J.; Weinshenker, B.G. The spectrum of neuromyelitis optica. Lancet Neurol. 2007, 6, 805-815. [CrossRef]

22. Bevan, C.; Gelfand, J.M. Therapeutic Management of Severe Relapses in Multiple Sclerosis. Curr. Treat. Options Neurol. 2015, 17, 17. [CrossRef] [PubMed]

23. Sellebjerg, F.; Barnes, D.; Filippini, G.; Midgard, R.; Montalban, X.; Rieckmann, P.; Selmaj, K.; Visser, L.H.; Sorensen, P.S. EFNS guideline on treatment of multiple sclerosis relapses: Report of an EFNS task force on treatment of multiple sclerosis relapses. Eur. J. Neurol. 2005, 12, 939-946. [CrossRef] [PubMed]

24. Wiendl, H.; Toyka, K.V.; Rieckmann, P.; Gold, R.; Hartung, H.P.; Hohlfeld, R. Basic and escalating immunomodulatory treatments in multiple sclerosis: Current therapeutic recommendations. J. Neurol. 2008, 255, 1449-1463. [PubMed]

25. Schroder, A.; Linker, R.A.; Gold, R. Plasmapheresis for neurological disorders. Expert Rev. Neurother. 2009, 9, 1331-1339. [CrossRef]

26. Padmanabhan, A.; Connelly-Smith, L.; Aqui, N.; Balogun, R.A.; Klingel, R.; Meyer, E.; Pham, H.P.; Schneiderman, J.; Witt, V.; Wu, Y.; et al. Guidelines on the Use of Therapeutic Apheresis in Clinical Practice-Evidence-Based Approach from the Writing Committee of the American Society for Apheresis: The Eighth Special Issue. J. Clin. Apher. 2019, 34, 171-354. [CrossRef]

27. Cortese, I.; Chaudhry, V.; So, Y.T.; Cantor, F.; Cornblath, D.R.; Rae-Grant, A. Evidence-based guideline update: Plasmapheresis in neurologic disorders: Report of the Therapeutics and Technology Assessment Subcommittee of the American Academy of Neurology. Neurology 2011, 76, 294-300. [CrossRef]

28. Paroder-Belenitsky, M.; Pham, H. Immunoadsorption, Transfusion Medicine and Hemostasis, 3rd ed.; Stacy Masucci: Cambridge, UK, 2019; pp. 497-500.

29. Available online: https://www.kompetenznetz-multiplesklerose.de/wp-content/uploads/2016/02/dgnkknms_ms-11_20140813.pdf (accessed on 20 May 2020). 
30. Navarro-Martinez, R.; Cauli, O. Therapeutic Plasmapheresis with Albumin Replacement in Alzheimer's Disease and Chronic Progressive Multiple Sclerosis: A Review. Pharmaceuticals 2020, 13, 28. [CrossRef]

31. Koziolek, M.; Muhlhausen, J.; Friede, T.; Ellenberger, D.; Sigler, M.; Huppke, B.; Gartner, J.; Muller, G.A.; Huppke, P. Therapeutic apheresis in pediatric patients with acute CNS inflammatory demyelinating disease. Blood Purif. 2013, 36, 92-97. [CrossRef]

32. Koziolek, M.J.; Tampe, D.; Bahr, M.; Dihazi, H.; Jung, K.; Fitzner, D.; Klingel, R.; Muller, G.A.; Kitze, B. Immunoadsorption therapy in patients with multiple sclerosis with steroid-refractory optical neuritis. J. Neuroinflamm. 2012, 9, 80. [CrossRef]

33. Jamshidian, A.; Kazemi, M.; Shaygannejad, V.; Salehi, M. The Effect of Plasma Exchange on the Expression of FOXP3 and RORC2 in Relapsed Multiple Sclerosis Patients. Iran. J. Immunol. 2015, 12, 311-318. [PubMed]

34. Stork, L.; Ellenberger, D.; Beissbarth, T.; Friede, T.; Lucchinetti, C.F.; Bruck, W.; Metz, I. Differences in the Reponses to Apheresis Therapy of Patients With 3 Histopathologically Classified Immunopathological Patterns of Multiple Sclerosis. JAMA Neurol. 2018, 75, 428-435. [CrossRef] [PubMed]

35. Khatri, B.O.; McQuillen, M.P.; Harrington, G.J.; Schmoll, D.; Hoffmann, R.G. Chronic progressive multiple sclerosis: Double-blind controlled study of plasmapheresis in patients taking immunosuppressive drugs. Neurology 1985, 35, 312-319. [CrossRef]

36. Weiner, H.L.; Dau, P.C.; Khatri, B.O.; Petajan, J.H.; Birnbaum, G.; McQuillen, M.P.; Fosburg, M.T.; Feldstein, M.; Orav, E.J. Double-blind study of true vs. sham plasma exchange in patients treated with immunosuppression for acute attacks of multiple sclerosis. Neurology 1989, 39, 1143-1149. [CrossRef]

37. Weinshenker, B.G.; O’Brien, P.C.; Petterson, T.M.; Noseworthy, J.H.; Lucchinetti, C.F.; Dodick, D.W.; Pineda, A.A.; Stevens, L.N.; Rodriguez, M. A randomized trial of plasma exchange in acute central nervous system inflammatory demyelinating disease. Ann. Neurol. 1999, 46, 878-886. [CrossRef]

38. Habek, M.; Barun, B.; Puretic, Z.; Brinar, V.V. Treatment of steroid unresponsive relapse with plasma exchange in aggressive multiple sclerosis. Ther. Apher. Dial. 2010, 14, 298-302. [CrossRef]

39. Schilling, S.; Linker, R.A.; Konig, F.B.; Koziolek, M.; Bahr, M.; Muller, G.A.; Paulus, W.; Gartner, J.; Bruck, W.; Chan, A.; et al. Plasma exchange therapy for steroid-unresponsive multiple sclerosis relapses: Clinical experience with 16 patients. Der Nervenarzt 2006, 77, 430-438. [CrossRef]

40. Trebst, C.; Reising, A.; Kielstein, J.T.; Hafer, C.; Stangel, M. Plasma exchange therapy in steroid-unresponsive relapses in patients with multiple sclerosis. Blood Purif. 2009, 28, 108-115. [CrossRef]

41. Magana, S.M.; Keegan, B.M.; Weinshenker, B.G.; Erickson, B.J.; Pittock, S.J.; Lennon, V.A.; Rodriguez, M.; Thomsen, K.; Weigand, S.; Mandrekar, J.; et al. Beneficial plasma exchange response in central nervous system inflammatory demyelination. Arch. Neurol. 2011, 68, 870-878. [CrossRef]

42. Dorst, J.; Fangerau, T.; Taranu, D.; Eichele, P.; Dreyhaupt, J.; Michels, S.; Schuster, J.; Ludolph, A.C.; Senel, M.; Tumani, H. Safety and efficacy of immunoadsorption versus plasma exchange in steroid-refractory relapse of multiple sclerosis and clinically isolated syndrome: A randomised, parallel-group, controlled trial. EClinicalMedicine 2019, 16, 98-106. [CrossRef]

43. Ehler, J.; Koball, S.; Sauer, M.; Mitzner, S.; Hickstein, H.; Benecke, R.; Zettl, U.K. Response to Therapeutic Plasma Exchange as a Rescue Treatment in Clinically Isolated Syndromes and Acute Worsening of Multiple Sclerosis: A Retrospective Analysis of 90 Patients. PLoS ONE 2015, 10, e0134583. [CrossRef]

44. Lipphardt, M.; Muhlhausen, J.; Kitze, B.; Heigl, F.; Mauch, E.; Helms, H.J.; Muller, G.A.; Koziolek, M.J. Immunoadsorption or plasma exchange in steroid-refractory multiple sclerosis and neuromyelitis optica. J. Clin. Apher. 2019, 34, 381-391. [CrossRef]

45. Deschamps, R.; Gueguen, A.; Parquet, N.; Saheb, S.; Driss, F.; Mesnil, M.; Vignal, C.; Aboab, J.; Depaz, R.; Gout, O. Plasma exchange response in 34 patients with severe optic neuritis. J. Neurol. 2016, 263, 883-887. [CrossRef]

46. Ruprecht, K.; Klinker, E.; Dintelmann, T.; Rieckmann, P.; Gold, R. Plasma exchange for severe optic neuritis: Treatment of 10 patients. Neurology 2004, 63, 1081-1083. [CrossRef]

47. Yucesan, C.; Arslan, O.; Arat, M.; Yucemen, N.; Ayyildiz, E.; Ilhan, O.; Mutluer, N. Therapeutic plasma exchange in the treatment of neuroimmunologic disorders: Review of 50 cases. Transfus. Apher. Sci. 2007, 36, 103-107. [CrossRef]

48. Meca-Lallana, J.E.; Hernandez-Clares, R.; Leon-Hernandez, A.; Genoves Aleixandre, A.; Cacho Perez, M.; Martin-Fernandez, J.J. Plasma exchange for steroid-refractory relapses in multiple sclerosis: An observational, MRI pilot study. Clin. Ther. 2013, 35, 474-485. [CrossRef] 
49. Ehler, J.; Koball, S.; Sauer, M.; Hickstein, H.; Mitzner, S.; Benecke, R.; Zettl, U.K. Therapeutic plasma exchange in glucocorticosteroid-unresponsive patients with Clinically Isolated Syndrome. Ther. Apher. Dial. 2014, 18, 489-496. [CrossRef]

50. Faissner, S.; Nikolayczik, J.; Chan, A.; Hellwig, K.; Gold, R.; Yoon, M.S.; Haghikia, A. Plasmapheresis and immunoadsorption in patients with steroid refractory multiple sclerosis relapses. J. Neurol. 2016, 263, 1092-1098. [CrossRef]

51. Correia, I.; Ribeiro, J.J.; Isidoro, L.; Batista, S.; Nunes, C.; Macario, C.; Borges, C.; Tomaz, J.; Sousa, L. Plasma exchange in severe acute relapses of multiple sclerosis-Results from a Portuguese cohort. Mult. Scler. Relat. Disord. 2018, 19, 148-152. [CrossRef]

52. Hauser, S.L.; Dawson, D.M.; Lehrich, J.R.; Beal, M.F.; Kevy, S.V.; Weiner, H.L. Immunosuppression and plasmapheresis in chronic progressive multiple sclerosis. Design of a clinical trial. Arch. Neurol. 1983, 40, 687-690. [CrossRef]

53. Medenica, R.D.; Mukerjee, S.; Huschart, T.; Corbitt, W. Interferon inhibitor factor predicting success of plasmapheresis in patients with multiple sclerosis. J. Clin. Apher. 1994, 9, 216-221. [CrossRef]

54. Giedraitiene, N.; Kaubrys, G.; Kizlaitiene, R.; Bagdonaite, L.; Griskevicius, L.; Valceckiene, V.; Stoskus, M. Therapeutic Plasma Exchange in Multiple Sclerosis Patients with Abolished Interferon-beta Bioavailability. Med. Sci. Monit. 2015, 21, 1512-1519.

55. Roesner, S.; Appel, R.; Gbadamosi, J.; Martin, R.; Heesen, C. Treatment of steroid-unresponsive optic neuritis with plasma exchange. Acta Neurol. Scand. 2012, 126, 103-108. [CrossRef]

56. Merle, H.; Olindo, S.; Jeannin, S.; Valentino, R.; Mehdaoui, H.; Cabot, F.; Donnio, A.; Hage, R.; Richer, R.; Smadja, D.; et al. Treatment of optic neuritis by plasma exchange (add-on) in neuromyelitis optica. Arch. Ophthalmol. 2012, 130, 858-862. [CrossRef]

57. Watanabe, S.; Nakashima, I.; Misu, T.; Miyazawa, I.; Shiga, Y.; Fujihara, K.; Itoyama, Y. Therapeutic efficacy of plasma exchange in NMO-IgG-positive patients with neuromyelitis optica. Mult. Scler. 2007, 13, 128-132. [CrossRef]

58. Wang, K.C.; Wang, S.J.; Lee, C.L.; Chen, S.Y.; Tsai, C.P. The rescue effect of plasma exchange for neuromyelitis optica. J. Clin. Neurosci. 2011, 18, 43-46. [CrossRef]

59. Lim, Y.M.; Pyun, S.Y.; Kang, B.H.; Kim, J.; Kim, K.K. Factors associated with the effectiveness of plasma exchange for the treatment of NMO-IgG-positive neuromyelitis optica spectrum disorders. Mult. Scler. 2013, 19, 1216-1218. [CrossRef]

60. Kim, S.H.; Kim, W.; Huh, S.Y.; Lee, K.Y.; Jung, I.J.; Kim, H.J. Clinical efficacy of plasmapheresis in patients with neuromyelitis optica spectrum disorder and effects on circulating anti-aquaporin-4 antibody levels. J. Clin. Neurol. 2013, 9, 36-42. [CrossRef]

61. Abboud, H.; Petrak, A.; Mealy, M.; Sasidharan, S.; Siddique, L.; Levy, M. Treatment of acute relapses in neuromyelitis optica: Steroids alone versus steroids plus plasma exchange. Mult. Scler. 2016, 22, 185-192. [CrossRef]

62. Aungsumart, S.; Apiwattanakul, M. Clinical outcomes and predictive factors related to good outcomes in plasma exchange in severe attack of NMOSD and long extensive transverse myelitis: Case series and review of the literature. Mult. Scler. Relat. Disord. 2017, 13, 93-97. [CrossRef]

63. Srisupa-Olan, T.; Siritho, S.; Kittisares, K.; Jitprapaikulsan, J.; Sathukitchai, C.; Prayoonwiwat, N. Beneficial effect of plasma exchange in acute attack of neuromyelitis optica spectrum disorders. Mult. Scler. Relat. Disord. 2018, 20, 115-121. [CrossRef]

64. Jiao, Y.; Cui, L.; Zhang, W.; Zhang, Y.; Wang, W.; Zhang, L.; Tang, W.; Jiao, J. Plasma Exchange for Neuromyelitis Optica Spectrum Disorders in Chinese Patients and Factors Predictive of Short-term Outcome. Clin. Ther. 2018, 40, 603-612. [CrossRef]

65. Mori, S.; Kurimoto, T.; Ueda, K.; Nakamura, M. Short-term effect of additional apheresis on visual acuity changes in patients with steroid-resistant optic neuritis in neuromyelitis optica spectrum disorders. Jpn. J. Ophthalmol. 2018, 62, 525-530. [CrossRef]

66. Kumar, R.; Paul, B.S.; Singh, G.; Kaur, A. Therapeutic Efficacy of Plasma Exchange in Neuromyelitis Optica. Ann. Indian Acad. Neurol. 2018, 21, 140-143.

67. Kleiter, I.; Gahlen, A.; Borisow, N.; Fischer, K.; Wernecke, K.D.; Hellwig, K.; Pache, F.; Ruprecht, K.; Havla, J.; Kumpfel, T.; et al. Apheresis therapies for NMOSD attacks: A retrospective study of 207 therapeutic interventions. Neurol. Neuroimmunol. Neuroinflamm. 2018, 5, e504. [CrossRef] 
68. Song, W.; Qu, Y.; Huang, X. Plasma exchange: An effective add-on treatment of optic neuritis in neuromyelitis optica spectrum disorders. Int. Ophthalmol. 2019, 39, 2477-2483. [CrossRef]

69. De Andres, C.; Anaya, F.; Gimenez-Roldan, S. Plasma immunoadsorption treatment of malignant multiple sclerosis with severe and prolonged relapses. Rev. Neurol. 2000, 30, 601-605.

70. Heigl, F.; Hettich, R.; Arendt, R.; Durner, J.; Koehler, J.; Mauch, E. Immunoadsorption in steroid-refractory multiple sclerosis: Clinical experience in 60 patients. Atheroscler. Suppl. 2013, 14, 167-173. [CrossRef]

71. Mauch, E.; Zwanzger, J.; Hettich, R.; Fassbender, C.; Klingel, R.; Heigl, F. Immunoadsorption for steroid-unresponsive multiple sclerosis-relapses: Clinical data of 14 patients. Der Nervenarzt 2011, 82, 1590-1595. [CrossRef]

72. Trebst, C.; Bronzlik, P.; Kielstein, J.T.; Schmidt, B.M.; Stangel, M. Immunoadsorption therapy for steroid-unresponsive relapses in patients with multiple sclerosis. Blood Purif. 2012, 33, 1-6. [CrossRef]

73. Hoffmann, F.; Kraft, A.; Heigl, F.; Mauch, E.; Koehler, J.; Harms, L.; Kumpfel, T.; Kohler, W.; Ehrlich, S.; Bayas, A.; et al. Tryptophan immunoadsorption during pregnancy and breastfeeding in patients with acute relapse of multiple sclerosis and neuromyelitis optica. Ther. Adv. Neurol. Disord. 2018, 11. [CrossRef] [PubMed]

74. Moldenhauer, A.; Haas, J.; Wascher, C.; Derfuss, T.; Hoffmann, K.T.; Kiesewetter, H.; Salama, A. Immunoadsorption patients with multiple sclerosis: An open-label pilot study. Eur. J. Clin. Investig. 2005, 35, 523-530. [CrossRef] [PubMed]

75. Schimrigk, S.; Adibi, I.; Eberl, A.; Selka, I.; Galle, J.; Schmidt, S.; Fritz, H.G.; Fassbender, C.; Klingel, R.; Fuchtemann, D.; et al. Immunoadsorption as Relapse Escalation Therapy for Multiple Sclerosis. Aktuel. Neurol. 2012, 39, 174-179.

76. Schimrigk, S.; Faiss, J.; Kohler, W.; Gunther, A.; Harms, L.; Kraft, A.; Ehrlich, S.; Eberl, A.; Fassbender, C.; Klingel, R.; et al. Escalation Therapy of Steroid Refractory Multiple Sclerosis Relapse with Tryptophan Immunoadsorption-Observational Multicenter Study with 147 Patients. Eur. Neurol. 2016, 75, 300-306. [CrossRef] [PubMed]

77. Faissner, S.; Nikolayczik, J.; Chan, A.; Gold, R.; Yoon, M.S.; Haghikia, A. Immunoadsorption in patients with neuromyelitis optica spectrum disorder. Ther. Adv. Neurol. Disord. 2016, 9, 281-286. [CrossRef]

78. Hohenstein, B.; Passauer, J.; Ziemssen, T.; Julius, U. Immunoadsorption with regenerating systems in neurological disorders -A single center experience. Atheroscler. Suppl. 2015, 18, 119-123. [CrossRef]

79. Muhlhausen, J.; Kitze, B.; Huppke, P.; Muller, G.A.; Koziolek, M.J. Apheresis in treatment of acute inflammatory demyelinating disorders. Atheroscler. Suppl. 2015, 18, 251-256. [CrossRef]

80. Llufriu, S.; Castillo, J.; Blanco, Y.; Ramio-Torrenta, L.; Rio, J.; Valles, M.; Lozano, M.; Castella, M.D.; Calabia, J.; Horga, A.; et al. Plasma exchange for acute attacks of CNS demyelination: Predictors of improvement at 6 months. Neurology 2009, 73, 949-953. [CrossRef]

81. Bramlage, C.P.; Schroder, K.; Bramlage, P.; Ahrens, K.; Zapf, A.; Muller, G.A.; Koziolek, M.J. Predictors of complications in therapeutic plasma exchange. J. Clin. Apher. 2009, 24, 225-231. [CrossRef]

82. Mokrzycki, M.H.; Kaplan, A.A. Therapeutic plasma exchange: Complications and management. Am. J. Kidney Dis. 1994, 23, 817-827. [CrossRef]

83. Samtleben, W.; Blumenstein, M.; Liebl, L.; Gurland, H.J. Membrane plasma separation for treatment of immunologically mediated diseases. Trans. Am. Soc. Artif. Intern. Organs 1980, 26, 12-16. [PubMed]

84. Sprenger, K.B.; Rasche, H.; Franz, H.E. Membrane plasma separation: Complications and monitoring. Artif. Organs 1984, 8, 360-363. [PubMed]

85. Kohler, W.; Bucka, C.; Klingel, R. A randomized and controlled study comparing immunoadsorption and plasma exchange in myasthenic crisis. J. Clin. Apher. 2011, 26, 347-355. [CrossRef] [PubMed]

86. Zollner, S.; Pablik, E.; Druml, W.; Derfler, K.; Rees, A.; Biesenbach, P. Fibrinogen reduction and bleeding complications in plasma exchange, immunoadsorption and a combination of the two. Blood Purif. 2014, 38, 160-166. [CrossRef]

87. Schneider-Gold, C.; Krenzer, M.; Klinker, E.; Mansouri-Thalegani, B.; Mullges, W.; Toyka, K.V.; Gold, R. Immunoadsorption versus plasma exchange versus combination for treatment of myasthenic deterioration. Ther. Adv. Neurol. Disord. 2016, 9, 297-303. [CrossRef]

88. Keegan, M.; Pineda, A.A.; McClelland, R.L.; Darby, C.H.; Rodriguez, M.; Weinshenker, B.G. Plasma exchange for severe attacks of CNS demyelination: Predictors of response. Neurology 2002, 58, 143-146. [CrossRef] 
89. Heigl, F.; Hettich, R.; Suckfuell, M.; Luebbers, C.W.; Osterkorn, D.; Osterkorn, K.; Canis, M. Fibrinogen/LDL apheresis as successful second-line treatment of sudden hearing loss: A retrospective study on 217 patients. Atheroscler. Suppl. 2009, 10, 95-101. [CrossRef]

90. Sim, F.J.; Zhao, C.; Penderis, J.; Franklin, R.J. The age-related decrease in CNS remyelination efficiency is attributable to an impairment of both oligodendrocyte progenitor recruitment and differentiation. J. Neurosci. 2002, 22, 2451-2459. [CrossRef]

91. Freedman, M.S.; De Stefano, N.; Barkhof, F.; Polman, C.H.; Comi, G.; Uitdehaag, B.M.; Casset-Semanaz, F.; Hennessy, B.; Lehr, L.; Stubinski, B.; et al. Patient subgroup analyses of the treatment effect of subcutaneous interferon beta-1a on development of multiple sclerosis in the randomized controlled REFLEX study. J. Neurol. 2014, 261, 490-499. [CrossRef]

92. Kleiter, I.; Gahlen, A.; Borisow, N.; Fischer, K.; Wernecke, K.D.; Wegner, B.; Hellwig, K.; Pache, F.; Ruprecht, K.; Havla, J.; et al. Neuromyelitis optica: Evaluation of 871 attacks and 1153 treatment courses. Ann. Neurol. 2016, 79, 206-216. [CrossRef]

93. Zekeridou, A.; Lennon, V.A. Aquaporin-4 autoimmunity. Neurol. Neuroimmunol. Neuroinflamm. 2015, 2, e110. [CrossRef] [PubMed]

94. Savransky, A.; Rubstein, A.; Rios, M.H.; Vergel, S.L.; Velasquez, M.C.; Sierra, S.P.; Marcarian, G.; Alba, R.; Pugliese, A.M.; Tenembaum, S. Prognostic indicators of improvement with therapeutic plasma exchange in pediatric demyelination. Neurology 2019, 93, 2065-2073. [CrossRef] [PubMed]

95. Goto, H.; Matsuo, H.; Nakane, S.; Izumoto, H.; Fukudome, T.; Kambara, C.; Shibuya, N. Plasmapheresis affects T helper type-1/T helper type-2 balance of circulating peripheral lymphocytes. Ther. Apher. 2001, 5, 494-496. [CrossRef] [PubMed]

(C) 2020 by the authors. Licensee MDPI, Basel, Switzerland. This article is an open access article distributed under the terms and conditions of the Creative Commons Attribution (CC BY) license (http://creativecommons.org/licenses/by/4.0/). 